Paedagogia Christiana

2/28 (20I I) - ISSN 1505-6872

Jarostaw Horowski*

Toruń

\title{
Turystyka w chrześcijańskiej edukacji ekologicznej
}

Konieczność zaangażowania chrześcijańskiej edukacji religijnej w przedsięwzięcia mające na celu ochronę przyrody nie budzi dziś wątpliwości. Za podjęciem tego wyzwania przemawia przede wszystkim stan naszej planety, której dewastacja na skutek nieprzemyślanej gospodarki człowieka jest tak daleko posunięta, że zagraża życiu na niej, także życiu człowieka. Dodatkowej motywacji do włączenia w edukację religijną problematyki ochrony przyrody dostarcza nauczanie Kościoła ${ }^{1}$, a zwłaszcza papieży ostatnich lat, w którym coraz intensywniej pojawiają się wątki ekologiczne. Kwestię odniesień człowieka do środowiska przyrodniczego podejmowali już: Paweł VI ${ }^{2}$ i Jan Paweł $\mathrm{II}^{3}$, a w wypowiedziach Benedykta XVI ekologia stała

* Dr Jarosław Horowski jest adiunktem w Katedrze Teorii Opieki i Wychowania na Wydziale Nauk Pedagogicznych Uniwersytetu Mikołaja Kopernika w Toruniu.

${ }^{1}$ Por. T. Ślipko, Ekologiczna doktryna Kościoła, w: T. Ślipko, A. Zwoliński, Rozdroża ekologii, Kraków 1999, s. 19-54; A. L. Szafrański, Ochrona środowiska w świetle ekologii, „Chrześcijanin a współczesność” 5 (1988), s. 7-9.

${ }^{2}$ Por. J. Grześkowiak, Teologiczne przesłanki odpowiedzialności za środowisko przyrodnicze, „Roczniki Teologiczno-Kanoniczne” 6 (1980), s. 9; T. Ślipko, Ruch ekologiczny w Polsce a Pan Bóg, w: tenże, Spacerem po etyce, Kraków 2010, s. 76.

${ }^{3}$ Zob. na ten temat np. S. Jaromi, Ekologia, w: A. Muszla (red.), Encyklopedia bioetyki. Personalizm chrześcijański, Radom 2009, s. 177-181; T. Poller, Bóg, człowiek, natura. Problematyka ekologiczna w nauczaniu Jana Pawła II, Kraków-Zakopane 2001; S. Jaromi, Stworzyciel i przyroda wedtug Jana Pawła II, w: A. Dyduch-Falniowska, M. Grzegorczyk, Z. Kijas, Z. Mirek (red.), Miedzy niebem a ziemią. Ku etyce ekologicznej, Kraków 2000, s. 263-281; M. Wyrostkiewicz, Ekologia ludzka. Osoba i jej środowisko z perspektywy teologicznomoralnej, Lublin 2007; J. Dębowski, Ekologia osoby ludzkiej w chrześcijańskim nauczaniu społecznym, 
się jednym z ważniejszych tematów ${ }^{4}$. Mówiąc więc o edukacji ekologicznej w ramach edukacji religijnej, realizowanej we wspólnotach chrześcijan, nie należy zadawać pytania «czy?», ale «jak» ma ona przebiegać: jakim zasadom powinna podlegać oraz z jakich metod i środków może korzystać? Artykuł ten ma za zadanie przyjrzenie się jedynie wycinkowi rzeczywistości, jaką jest chrześcijańska edukacja religijna w zakresie ekologii, a mianowicie podejmuje on problem możliwości wykorzystania turystyki jako metody we wskazanym obszarze edukacji religijnej. Przy czym chodzi o turystykę, która prowadzi do kontaktu z przyrodą, a nie o pielgrzymowanie czy turystykę religijną ${ }^{5}$ Podejmowane poszukiwania będą zatem organizowane przez pytanie, jaki jest potencjał turystyki w zakresie chrześcijańskiej edukacji religijnej dotyczącej ekologii. Zainteresowanie turystyką wynika z przeświadczenia, że mimo niereligijnej motywacji, jaka towarzyszy uczestnikom wycieczek

Olsztyn 2001, s. 129-142; J. Brusiło, Przyroda w antropologii i teologii Jana Pawła II, w: M. Ostrowski, I. Sołjan (red.), Przyroda, geografia, turystyka w nauczaniu Jana Pawta II, Kraków 2007, s. 55-60.

${ }^{4}$ Refleksji na temat ochrony środowiska Benedykt XVI poświęcił uwagę w encyklice o integralnym rozwoju ludzkim w miłości i prawdzie Caritas in veritate, „L'Osservatore Romano" 9 (2009), s. 4-35. Ochrona środowiska stała się przedmiotem rozważań również w innych dokumentach i wypowiedziach, przykładowo: Osoba ludzka sercem pokoju, „L'Osservatore Romano” 2 (2007), s. 4-9; Rodzina wspólnota pokoju, „L'Osservatore Romano” 1 (2008), s. 25-28; Zwalczanie ubóstwa droga do pokoju, „L'Osservatore Romano” 1 (2009), s. 3-9; Jeśli chcesz krzewić pokój, strzeż dzieła stworzenia, „L'Osservatore Romano” 1 (2010), s. 4-8; Droga pokory nie jest droga rezygnacji, lecz odwagi, „L'Osservatore Romano” 10-11 (2007), s. 9-11; Boże Narodzenie świętem odrodzonego stworzenia, „L'Osservatore Romano” 2 (2008), s. 17-18; Niech Duch Święty odnowi ten kraj, „L'Osservatore Romano” 9 (2008), s. 11-12; Ochrona środowiska jest ściśle związana z integralnym rozwojem człowieka, „L'Osservatore Romano" 10 (2009), s. 34-35; Musimy jak najszybciej zwalczyć głód i niedożywienie na świecie, „L'Osservatore Romano” 1 (2010), s. 22-24; Miłość bliźniego i sprawiedliwość w stosunkach międzynarodowych i międzypaństwowych, „L'Osservatore Romano” 7-8 (2007), s. 5-7. Na temat nauczania Benedykta XVI o ekologii zob. J. Horowski, Rozwój człowieka w kontekście relacji do środowiska przyrodniczego - ws świetle encykliki Benedykta XVI «Caritas in veritate», „Collectanea Theologica” 2 (2010), s. 65-82.

${ }^{5}$ Pielgrzymka jest specyficzną formą podróży, podejmowaną ze względu na motywację religijną. Różni się od niej turystyka religijna, w której - mimo tego samego co w przypadku pielgrzymki celu podróży - przeważają elementy poznawcze. W skrajnych przypadkach taka turystyka może przybrać postać turystyki religioznawczej, która rozwija się w wyniku przemian współczesnej kultury. Por. A. Jackowski, Pielgrzymki a turystyka religijna. Rozważania na czasie, w: Z. Kroplewski, A. Panasiuk (red.), Turystyka religijna, Szczecin 2010, s. 27-29; K. Wojtkiewicz, Pielgrzymowanie jako szukanie Boga, w: Z. Kroplewski, A. Panasiuk (red.), dz. cyt., s. 33; A. Maron, Turysta a pielgrzym - różnice motywacji poznawczej, w: Z. Kroplewski, A. Panasiuk (red.), dz. cyt., s. 72-75; M. Ostrowski, Jan Paweł II o świętej przestrzeni pielgrzymowania, w: M. Ostrowski, I. Sołjan (red.), dz. cyt., s. 43. 
w góry, spływów kajakowych czy wędrówek po lasach ${ }^{6}$, doświadczenia związane z tymi wyprawami wpisują się w teleologię chrześcijańskiej edukacji ekologicznej. Aby rozwiązać zasygnalizowany problem, konieczne jest jednak najpierw udzielenie odpowiedzi na szereg pytań związanych kolejno z etyką, moralnością i wychowaniem moralnym. Dopiero wówczas będzie możliwe rozstrzygnięcie głównego problemu badań. Przyjrzyjmy się tym zagadnieniom.

\section{Specyfika etyki chrześcijańskiej}

Chrześcijańska edukacja ekologiczna odwołuje się do chrześcijańskiego spojrzenia na rzeczywistość stworzoną oraz wynikającej z niego etyki w dziedzinie ekologii. Udzielenie odpowiedzi na postawione we wstępie pytanie wymaga więc przynajmniej pobieżnego naświetlenia, czym są: «chrześcijańskie spojrzenie» i «chrześcijańska etyka». Powołam się tutaj na myśl Józefa Marii Bocheńskiego ze względu na jej charakter analityczny. Oznacza to w gruncie rzeczy odwołanie się do tomizmu, gdyż Bocheński uznawał język filozofii św. Tomasza za odpowiednie narzędzie do ,rozszyfrowania rzeczywistości"7. Myśl Akwinaty miała dla Bocheńskiego szczególną wartość, ponieważ św. Tomasz wyraźne rozróżnił filozofię i teologię ${ }^{8}$ Z perspektywy podejmowanego przez nas zagadnienia jest to bardzo istotne.

Mówiąc o etyce, Bocheński wyróżnia dwa rodzaje zasad: naturalne i te, które nie pochodzą z natury. Do pierwszych zalicza na przykład zasadę sprawiedliwości ${ }^{9}$, do drugich chociażby zasadę miłości nieprzyjaciół ${ }^{10}$. O zasadach pochodzących z natury Bocheński mówi, odwołując się do filozofii Arystotelesa: „To jest Arystoteles. Stare greckie powiedzenie - żyć zgodnie z naturą. [...] Czym jest dobro moralne? Tym, co zgodne z naturą. Natura jest na przykład tak urządzona, że każde zwierzę żyjące, każda roślina stara się zachowywać swój gatunek, uwieńczyć go. Dlatego nie należy zabijać dzieci, należy im dać jeść, opiekować się nimi. To jest przykład, w jakim sensie moralność ma podstawy biologiczne"11. Zasady, które nie pochodzą

${ }^{6}$ Zob. typologię motywacji do podjęcia aktywności turystycznej: R. Winiarski, J. Zdebski, Psychologia turystyki, Warszawa 2008, s. 39-53; K. Przecławski, Turystyka a wychowanie, Warszawa 1973, s. 46-49.

7 J. M. Bocheński, Między logika a wiarą. Z Józefem M. Bocheńskim rozmawia Jan Parys, Paris 1992, s. 28.

8 Por. tenże, Zarys historii filozofii, Kraków 1993, s. 128.

9 Por. tenże, Między logika, s. 196.

10 Por. tamże, s. 207; tenże, Podręcznik mądrości tego świata, Kraków 1994, s. 112.

11 Tenże, Między logika, s. 207; por. tenże, ABC tomizmu, Londyn 1950, s. 55. 
z natury, wynikają ze światopoglądu. Bocheński definiuje światopogląd jako „zespół zdań, wyjaśniających całość doświadczenia człowieka, i to nie tylko doświadczenia faktów, ale także wartości”'12. Owe zdania zawierają pewne wythumaczenie świata, odpowiedź na pytania egzystencjalne, na przykład na pytanie o sens życia, i wreszcie zespół norm, praw moralnych ${ }^{13}$. Zdań tych nie da się udowodnić. Przyjmowane są one na drodze wiary, czyli uznawane są za prawdziwe pod wpływem woli ${ }^{14}$. Zdaniem Bocheńskiego, światopogląd wynika między innymi z religii ${ }^{15}$. Biorąc pod uwagę, że człowiek jest w stanie udowodnić jedynie zdania, opisujące rzeczywistość materialną, należy stwierdzić, że w wielu życiowo ważnych kwestiach musi on odwoływać się do światopoglądu, przyjmując określone założenia ontologiczne, antropologiczne czy epistemologiczne. Swoje stanowisko Bocheński wyraża w słowach: „Odpowiedzi na zagadnienia egzystencjalne nie można uzasadnić naukowo, podobnie jak norm moralnych. Dlatego gadanie o światopoglądzie naukowym uważam za zupełne nieporozumienie. Przy czym takie podejście zakłada, że nauka jest czymś takim jak światopogląd. A światopogląd nie jest nauką i nie składa się tylko z twierdzeń. Zwykle podkreśla się w nim treści uczuciowe, uczucia w stosunku do świata" ${ }^{16}$.

$\mathrm{Z}$ tego krótkiego wywodu, zbudowanego w odwołaniu do myśli Józefa Bocheńskiego, wynikają istotne wnioski dla etyki w zakresie relacji między człowiekiem i przyrodą. Po pierwsze, istnieją prawdy, które człowiek może poznać na drodze rozumu. Z pewnością należą do nich te, które dotyczą wpływu konkretnych działań człowieka na poszczególne elementy biosfery, oraz wynikające $\mathrm{z}$ nich postulaty, odnośnie do pożądanych zachowań człowieka $w$ relacjach ze środowiskiem przyrodniczym. Po drugie, w dziedzinie postaw wobec przyrody istnieje potrzeba przyjęcia wielu twierdzeń w ramach światopoglądu. W konsekwencji człowiek staje wobec konieczności zinterpretowania świata, a w nim roślin, zwierząt i samego siebie, jak również odnalezienia sensu własnego życia w kontekście, w którym funkcjonuje. Chrześcijaństwo proponuje takie twierdzenia w ramach teologii moralnej. Równocześnie człowiek styka się z wieloma alternatywnymi światopoglądami w tej dziedzinie, na przykład z ekologią głęboką, filozofią ekologicz-

12 Tenże, Sto zabobonów. Krótki filozoficzny stownik zabobonów, Warszawa 1988, s. 106.

13 Por. tenże, Między logika, s. 164.

${ }_{14}$ Por. tenże, Wiara, w: tenże, Szkice etyczne, Londyn 1953, s. 9

${ }^{15}$ Por. tenże, Między logika, s. 161. Przy czym Bocheński wyraźnie stwierdza, że chrześcijaństwo nie tworzy ideologii, mówiąc: „Natomiast ideologia to światopogląd, który posiada przynajmniej jeszcze jedną dodatkową cechę: zawiera receptę na poprawę świata, której na przykład, chrześcijaństwo nie zawiera". Tamże, s. 164.

16 Tamże, s. 164. 
ną Henryka Skolimowskiego (eko-filozofią), filozofią Gai, enwironmentalizmem czy ekofeminizmem, funkcjonującymi w ramach biocentrycznego nurtu ekofilozofii. Implikują one nie tylko teorię rzeczywistości, niejednokrotnie zakładając panteizm, ale wskazują także na określony sens ludzkiego życia, kwestionując transcendentne odniesienia człowieka ${ }^{17}$. Jak skonstruowana jest zatem chrześcijańska myśl etyczna w dziedzinie ekologii?

\section{Chrześcijańska myśl etyczna w dziedzinie ekologii}

Jak zostało stwierdzone w poprzednim punkcie, chrześcijańska teoria moralności odwołuje się do poznania naturalnego oraz teologii. Poznanie naturalne interpretowane jest zgodnie z założeniami filozofii arystotelesowsko-tomistycznej. W dziedzinie ekologii oznacza to chociażby odwołanie do argumentacji teleologicznej. Argument teleologiczny wynika ze stwierdzenia istnienia celów w strukturze bytów naturalnych oraz ontologicznego ugruntowania dobra, czyli osadzenia dobra w bycie. Argument teleologiczny wskazuje, że jeżeli w przyrodzie istnieją cele, które człowiek rekonstruuje jako roszczenia jakiegoś dobra samego w sobie, to ta teleologiczna struktura bytu zobowiązuje człowieka do bezwarunkowej afirmacji owego dobra, zgodnie $\mathrm{z}$ teleologiczną naturą bytu ${ }^{18}$.

17 Por. B. Devall, G. Sessions, Ekologia głęboka, Warszawa 1995, s. 93-97; S. Konstańczak, Wybrane zagadnienia ekofilozofii, Słupsk 2005, s. 105-107; D. Liszewski, Ekologia głęboka w pigułce, cz.1, „Dzikie Życie” 7-8 (2000), s. 9; H. Skolimowski, Humanizm ekologiczny. Odpowiedź na pytanie: „Dokąd zmierzamy?”, w: A. Papuziński, Z. Hull (red.), Wokót eko-filozofii. Księga jubileuszowa ofiarowana Profesorowi Henrykowi Skolimowskiemu dla uczczenia siedemdziesięciolecia urodzin, Bydgoszcz 2001, s. 222-224; tenże, Medytacje o nędzach cywilizacji technicznej i o blaskach życia ludzkiego, Londyn 1979, s. 12-17, 74; tenże, Filozofia żyjaca. Eko-filozofia jako drzewo życia, Warszawa 1992, s. 11-12, 25-27; R. Kulik, Odkrywanie natury. Praktyka głębokiej ekologii, Bystra 2007, s. 47-50; Z. Hull, Ekofilozofia i etyka środowiskowa - czy etyka środowiskowa jest częścia ekofilozofii?, w: K. Kalka, A. Papuziński (red.), Etyka wobec współczesnych dylematów, Bydgoszcz 2006, s. 310-312; tenże, Filozofia ekologii jako nowa dziedzina filozofowania, w: W. Tyburski (red.), Ekofilozofia i bioetyka. Materiały VI Polskiego Zjazdu Filozoficznego w Toruniu, Toruń 1996, s. 12, 16; Z. Piątek, Dylematy etyki środowiskowej, w: W. Tyburski (red.), dz. cyt., s. 53-55; Z. Wróblewski, Uwagi na temat kontrowersji antropocentryzm - biocentryzm w etyce ekologicznej, w: J. W. Czartoszewski (red.), Etyka środowiskowa wyzwaniem XXI wieku, Warszawa 2002, s. 73; J. Horowski, Harmonia między człowiekiem i przyroda jako wyzwanie dla pedagogiki chrześcijańskiej, w: J. Michalski, A. Zakrzewska (red.), Pedagogika chrześcijańska. Tradycja - współczesność - nowe wyzwania, Torun 2010, s. 104-109.

18 Por. Z. Wróblewski, Natura - cele naturalne - wartości i normy. Analiza argumentu teleologicznego w ujęciu praktycznej filozofii przyrody, „Studia Philosophiae Christianae” 1 (2009), s. 202-203. 
$\mathrm{Na}$ argumentację, która powstaje na drodze poznania naturalnego, nakłada się perspektywa teologiczna, z której wynika kilka podstawowych prawd. Po pierwsze, uznanie, że świat jest dobrym dziełem, kochanym przez Boga ${ }^{19}$, będącym przedmiotem Jego troski ${ }^{20}$ i posiadającym immanentne cele wpisane w swoje istnienie - świat ma swym istnieniem składać chwałę $\mathrm{Bogu}^{21}$. Jednak wynikająca z Biblii teleologia świata nie ogranicza się wyłącznie do rzeczywistości doczesnej. Świat wpisuje się także w rzeczywistość eschatologiczną. Jak mówi Jacek Salij, w czasach ostatecznych ,nie tylko dopełni się [...] ostatecznie i na zawsze przebóstwienie całej ludzkości, ale nastąpi również jakieś tajemnicze odnowienie materialnego wszechświata, który stanie się «nowym niebem i nową ziemią)"22. Po drugie, człowiek (będący, z jednej strony, częścią świata, a z drugiej odmienny od innych bytów) ma wobec świata do spełnienia określoną rolę, która wynika z jego powołania

${ }^{19}$ Najbardziej dobitnie miłość tę wyrażają słowa z Księgi Mądrości „Miłujesz bowiem wszystkie stworzenia, / niczym się nie brzydzisz, co uczyniłeś [...]. Oszczędzasz wszystko, bo to wszystko Twoje, Panie, miłośniku życia" $(11,24$. 26). Por. J. Suchy, Czyńcie sobie ziemię poddana, panujcie nad zwierzętami, „Zeszyty Naukowe KUL” 1-4 (1993), s. 20-21; W. Bołoz, Biblijne podstawy ekoteologii, w: J. M. Dołęga, J. W. Czartoszewski, A. Skowroński (red.), Ochrona środowiska społeczno-przyrodniczego w filozofii i teologii, Warszawa 2001, s. 352-353; J. Grzesica, Ochrona środowiska naturalnego człowieka, Katowice 1993, s. 72; J. Łukomski, Solidarność człowieka z przyroda, Radom 1994, s. 25; D. G. Deffenbaugh, D. L. Dungan, Biblia i ekologia, w: W. R. Farmer, S. McEvenue, A. J. Levoratti, D. L. Dungan (red.), Międzynarodowy komentarz do Pisma Świętego: komentarz katolicki i ekumeniczny, Warszawa 2001, s. 1763.

${ }^{20}$ Warto przytoczyć chociażby słowa z Księgi Psalmów: „On daje pokarm bydłu, pisklętom kruka to, o co wołają" (Ps 147, 9; por. Ps 145, 15-16). Zob. także: C. Naumowicz, Eko-teologia jako forma chrześcijańskiej diakonii wobec stworzenia, „Studia Ecologiae et Bioethicae" 1 (2009), s. 229; W. Bołoz, dz. cyt., s. 347-348, 353, 355; S. Zięba, Religia a ekologia, w: tenże (red.), Konferencje ekologiczne, Lublin 1995, s. 18; P. Kędzierski, Kościót i ekologia, Rzeszów 1997, s. 50.

${ }^{21}$ Por. J. Moltmann, Bóg w stworzeniu, Kraków 1995, s. 40-41; J. Salij, Gwiazdy, ludzie i zwierzęta, Kraków 2009, s. 128; J. Synowiec, Wprowadzenie do Księgi Psalmów, Kraków 1996, s. 271-272; R. Rubinkiewicz, Prorocza wizja odnowionego świata, „Zeszyty Naukowe KUL" 1-4 (1993), s. 36-37; R. Rogowski, Teoekologia. Mistyka wszystkich rzeczy, Kraków 2002, s. 113-116, 133-146; S. Zięba, dz. cyt., s. 16. Prawdę tę podkreślił Jan Paweł II w orędziu na Światowy Dzień Pokoju w 1990 roku: „Szacunek dla życia i dla ludzkiej godności zakłada także poszanowanie dla stworzenia i troskę o nie, gdyż jest ono wezwane, by wspólnie z człowiekiem chwalić Boga" (nr 16). Jan Paweł II, Pokój z Bogiem Stwórca, pokój z całym stworzeniem, „L'Osservatore Romano” 12 (1989), s. 21-22.

22 J. Salij, dz. cyt., s. 77; por. także: Cz. S. Bartnik, Dogmatyka katolicka, t. 2, Lublin 2003, s. 922-923; J. Moltmann, dz. cyt., s. 42-44; R. Rogowski, „Staraj się chwalić jego dzieta” (Job 36, 24). Biblia i ksztaltowanie postaw proekologicznych, w: M. Ostrowski, J. Partyka (red.), Elementy chrześcijańskie w edukacji ekologicznej, Ojców 2008, s. 14-17; W. Knoch, Świat-dobre stworzenie Boga?, „Communio” 6 (1992), s. 10; P. Kędzierski, dz. cyt., s. 74-75; S. Zięba, dz. cyt., s. 15; D. G. Deffenbaugh, D. L. Dungan, dz. cyt., s. 1766-1769. 
do bycia „na obraz i podobieństwo Boga” ( $R d z$ 1, 26-27). Człowiek ma sprawiać, aby rzeczywistość stworzona, którą powierzono jego opiece, była coraz doskonalsza - został powołany do „uprawiania i doglądania” ogrodu Eden (por. Rdz 2, 15) 23. Po trzecie, konieczność troski o przyrodę nie oznacza stawiania jej w hierarchii wartości wyżej od człowieka. Fundamentem dla tej tezy jest prawda, że człowiek tylko wtedy, gdy przyczynia się do doskonałości stworzonego świata, rozwija się jako człowiek i staje się na obraz Boga, natomiast wówczas, gdy przyjmuje wobec przyrody postawę eksploatatora i konsumenta, degraduje własne człowieczeństwo. Troska o przyrodę jest więc równocześnie troską o człowieka, zabiegami o ecologia humana ${ }^{24}$.

Myśl teologiczna na temat relacji człowieka do stworzonego świata jest niezwykle bogata. Nie sposób przedstawić jej tutaj nawet w zarysie. Nie to jest zresztą celem niniejszych poszukiwań. Biorąc pod uwagę główne pytanie, stawiane w tekście, należy podkreślić dwie prawdy. Po pierwsze, chrześcijańska myśl etyczna w dziedzinie ekologii oparta jest na dwóch rodzajach przesłanek. Pierwsze wynikają z natury rzeczywistości i odkrywane są na drodze poznania rozumowego. Drugie odczytywane są z biblijnego Objawienia. Po drugie, chrześcijańska etyka nie jest sprzeczna z tym, co człowiek odkrywa na drodze rozumu, ale umieszcza jego odkrycia w transcendentnej perspektywie, nadając im teologiczną interpretację. Konstatacje te są istotne dla odpowiedzi na pytanie o rolę turystyki w przekazie chrześcijańskiej perspektywy patrzenia na świat oraz na sposób odniesień do niego.

${ }^{23}$ Por. J. Bagrowicz, „Czyńcie sobie ziemię poddana ...” (Rdz 1,28), czyli jak doglądać i uprawiać ogród Eden, w: B. Przyborowska (red.), Natura, edukacja, kultura. Pedagogia źródet, Toruń 2006, s. 97-100; R. Guardini, Bóg daleki - Bóg bliski, Poznań 1991, s. 47-52; J. Salij, dz. cyt., s. 120; W. Bołoz, dz. cyt., s. 343; J. Synowiec, Na poczatku. Pradzieje biblijne: $R d z$ 1,1-11,9, Kraków 1996, s. 74; M. Filipiak, Problematyka społeczna w Biblii, Warszawa 1985, s. 194-203; G. Witaszek, Kościót wobec ekologii, „Zeszyty Naukowe KUL” 1-4 (1993), s. 44-48; J. Dębowski, dz. cyt., s. 16-17; J. Łukomski, Próba zbudowania chrześcijańskiej etyki środowiska naturalnego, Kielce 2000, s. 341-345; W. Knoch, dz. cyt., s. 5-6; J. Grześkowiak, dz. cyt., s. 12-13; P. Kędzierski, dz. cyt., s. 54-57. Zniszczenie przyrody jest więc w każdym wypadku konsekwencją działania człowieka, jest skutkiem jego grzechu. Prawdę tę wyrażają nawet obrazy, w których to nie bezpośrednie działanie człowieka jest przyczyną zniszczenia, na przykład opowiadanie o potopie. Por. L. Stachowiak, Akcenty ekologiczne w opisie potopu. Rdz 6-9, „Roczniki Teologiczne” 1 (1991-1992), s. 17-25; J. Suchy, Ekologiczne przestanie Biblii, w: G. Witaszek (red.), Życie społeczne w Biblii, Lublin 1997, s. 182n; D. G. Deffenbaugh, D. L. Dungan, dz. cyt., s. 1764-1765.

24 Por. S. Jaromi, Ekologia, s. 177-178; J. Brusiło, Założenia chrześcijańskiej ekologiiaspekt etyczny, w: M. Ostrowski, J. Partyka (red.), dz. cyt., s. 43-47; G. Witaszek, Kościót, s. 51. 


\section{Turystyka a przekaz chrześcijańskiej teorii moralnej}

Jeżeli zakładamy, że poznanie naturalne i teologia wzajemnie się uzupełniają, to chcąc uczyć dojrzewającego człowieka chrześcijańskiego podejścia do stworzonego świata, należy odwołać się do nich obu. Arne Naess, jeden z twórców ekologii głębokiej, zupełnie obcej chrześcijaństwu koncepcji ekofilozoficznej sytuującej się w nurcie biocentrycznym, wyraża w swoich pismach przekonanie, że człowiekowi potrzebny jest kontakt choć ze skrawkiem dzikiej przyrody, aby mógł dostrzec immanentną wartość bytów pozaludzkich. Stwierdza na przykład, że chcąc chronić rzekę przed wielkimi budowlami inżynierskimi, należy przede wszystkim zaprosić budowniczych na spacer wzdłuż rzeki, aby nacieszyli się różnymi widokami jej swobodnych procesów, różnorodnością życia ${ }^{25}$. Abstrahując od światopoglądowych uwikłań ekologii głębokiej, należy przyznać, że Arne Naess zwraca uwagę na bardzo istotną kwestię odkrycia wartości przyrody na drodze poznania naturalnego, jako na podstawę budowania każdego światopoglądu, uwzględniającego odniesienia do przyrody. Również edukacja chrześcijańska nie może zapominać o poznaniu naturalnym.

Turystyka jawi nam się w pierwszym rzędzie właśnie jako metoda poznania naturalnego, jako droga wprowadzenia w doświadczenie rzeczywistości i odkrywania jej immanentnej wartości. Należy zauważyć, że czymś innym jest uczenie się o dobru w ramach edukacji szkolnej, a czymś innym doświadczanie immanentnej wartości rzeczywistości w kontakcie $\mathrm{z}$ nią. Turystyka pozwala odkryć to, co często pozostaje niezauważone przez ucznia w ramach procesu dydaktycznego ${ }^{26}$, szczególnie gdy na co dzień żyje w sztucznym, zniekształconym i zanieczyszczonym otoczeniu cywilizacji technicznej. Turystyka to okazja do kontemplacji piękna przyrody, do dostrzeżenia nie tylko piękna gór, wodospadów, lasów czy jezior, ale także panującego w przyrodzie porządku, ładu. Turysta ma szansę na odkrycie tego, co niezwykłe: potęgi, różnorodności, niezwykłości, bogactwa kształtów, kolorów, dźwięków ${ }^{27}$. Turystyka pozwala również odkryć skutki działalno-

${ }^{25}$ Por. A. Naess, Musimy stuchać swoich uczuć, w: A. J. Korbel (red.), O przyrodzie i człowieku. Rozmowy Dzikiego Życia, Bielsko-Biała 2001, s. 18.

${ }^{26}$ Por. K. Denek, W kręgu edukacji, krajoznawstwa i turystyki w szkole, Poznań 2000, s. 133-141, 143-147; tenże, Edukacja pozalekcyjna i pozaszkolna, Poznań 2009, s. 168-173; K. Przecławski, Turystyka, s. 70; I. Janowski, Metodyka wycieczek szkolnych, Kielce 2004, s. 31-33; R. Winiarski, J. Zdebski, dz. cyt., s. 101-105.

27 Por. L. Turos, Turystyka i inteligencja emocjonalna, Warszawa 2002, s. 104; M. Ostrowski, Jana Pawła II szlaki - refleksja o chrześcijańskiej turystyce, w: XIII Seminarium , Sacrum i przyroda". W stulecie Orlej Perci, Zakopane 2005, s. 18. 
ści człowieka, zarówno te pozytywne, jak i negatywne. Pozwala zobaczyć, kiedy przyczynia się on do dobra przyrody, a kiedy prowadzi do jej dewastacji. Co więcej, w niektórych sytuacjach pozwala ona doświadczać skutków własnych odniesień do przyrody, a więc pozwala doświadczać wartości moralnych w sferze odniesień człowieka do świata przyrody.

Turystyka sama w sobie wydaje się z kolei niezdolna do przekazu tego, co w dziedzinie chrześcijańskiej myśli ekologicznej wynika z Objawienia. W edukacji chrześcijańskiej nieodzowna jest zatem refleksja, odwołująca się do Biblii oraz interpretującej ją teologii ${ }^{28}$. Warto jednak pamiętać, że próby spojrzenia z chrześcijańskiej perspektywy na odniesienia do stworzonego świata powinny być budowane na poznaniu naturalnym. Szkolne lekcje religii przekazują treści z zakresu ekoteologii ${ }^{29}$. Jeżeli jednak brak im odwołania do poznania naturalnego, w świadomości ucznia nie spotykają się one z odpowiednią uwagą. Wykorzystanie obrazów strumienia, górskiego łańcucha czy lasu, jako pomocy dydaktycznych, nie jest tym samym, co zaprowadzenie ucznia nad brzeg strumienia, na szczyt góry czy na leśną wędrówkę. W sferze wprowadzania w teorię chrześcijańską należy więc łączyć te dwa spojrzenia: naturalne i teologiczne. Myśl tę znajdujemy także w nauczaniu Kościoła. Za przykład niech posłuży fragment dokumentu Papieskiej Rady ds. Duszpasterstwa Migrantów i Podróżnych, zatytułowanego Wskazania dla duszpasterstwa turystycznego:

Turystyka i przyroda pozostają ze sobą w ścisłym związku. Wtłoczony w codzienne życie zdominowane przez technikę turysta dąży do poszukiwania bezpośredniego kontaktu z przyrodą, zażywania piękna krajobrazu, poznania zwyczajów zwierząt oraz jest gotowy do ponoszenia trudów i niebezpieczeństw. Krótko mówiąc, przyroda stanowi idealne miejsce do uprawiania i rozwijania turystyki. Poprzez wzrastające zrozumienie środowiska naturalnego zmienia się również coraz bardziej stosunek człowieka do przyrody. Człowiek musi się uczyć, zgodnie z przykładem św. Franciszka z Asyżu, dostrzegania we wszystkich stworzeniach swoich braci, aby w ten sposób przyjść do Stwórcy i powiedzieć: «Bądź pochwalony, mój Panie, ze wszystkimi Twoimi stworzeniami»» ${ }^{30}$.

${ }^{28}$ Por. G. Witaszek, Kościót, s. 51-56.

${ }^{29}$ Zob. S. Dziekoński, Problematyka ekologiczna w posoborowych katechetycznych dokumentach Kościoła, w: J. M. Dołęga, J. W. Czartoszewski, A. Skowroński (red.), dz. cyt., s. 233-244; tenże, Teologiczne podstawy wychowania ekologicznego w katechezie, „Ateneum Kapłańskie" 3 (2002), s. 481-496.

${ }^{30}$ Papieska Rada ds. Duszpasterstwa Migrantów i Podróżnych, Wskazania dla duszpasterstwa turystycznego, $\mathrm{nr} 8, \mathrm{w}$ : M. Ostrowski (red.), Duszpasterstwo pielgrzymów i turystów. Wybór wypowiedzi i dokumentów kościelnych, Kraków 2003, s. 139. 
Zajmijmy się teraz kwestią wychowania ekologicznego, mając świadomość, że zmiany w człowieku nie dokonują się jedynie pod wpływem poznania, czy to naturalnego, czy wynikającego ze spotkania z chrześcijańską doktryną moralną.

\section{Etyka a moralność, kształcenie a wychowanie}

Pytanie o metody i środki edukacji ekologicznej wynika z przekonania, że nie wystarczy zbudowanie spójnego systemu etycznego odnoszącego się do kwestii ekologii, aby zmienić postawy poszczególnych ludzi w dziedzinie odniesień do przyrody. Moralność nie jest bowiem konsekwencją etyki. U wielu osób znajomość norm moralnych w określonych dziedzinach nie idzie w parze z ich zachowywaniem. Nie mają oni bowiem wystarczającej motywacji do ich realizacji. Aby poszukiwać odpowiedzi na pytanie o metody i środki edukacji ekologicznej, przyjrzyjmy się zatem najpierw specyfice samej moralności. Przewodnikiem niech będzie tym razem Jacek Woroniecki, teolog, który uważał, że kwestie moralne powinny być analizowane w kontekście pedagogiki.

Budując fundament dla swojej teorii wychowania, Jacek Woroniecki wyróżnił cztery rodzaje wiedzy, do jakiej dochodzi rozum. Są nimi wiedza teoretyczna, praktyczno-teoretyczna, praktyczna habitualna i praktyczna aktualna. Wiedza teoretyczna oraz praktyczno-teoretyczna dotyczą teorii odpowiednio niezwiązanej oraz związanej z praktyką, ale zdobywanej poza kontekstem praktyki, czyli nie pod kątem czynu. Inaczej jest w przypadku wiedzy praktycznej habitualnej i praktycznej aktualnej. Pierwszy rodzaj wiedzy pojawia się wówczas, gdy rozważamy jakąś czynność pod kątem jej ewentualnego wykonania, gdyby pojawiła się taka konieczność; drugi związany jest z natychmiastową decyzją. Różnica między nimi polega na tym, że o ile wiedza praktyczna habitualna osiągana jest przez rozum, to wiedza praktyczna aktualna jest efektem dialogu, toczonego między rozumem i wolą, w którym na wolę wpływają ponadto uczucia ${ }^{31}$. Działanie woli polega na dążeniu do dobra, co w perspektywie subiektywnej wyraża się w dążeniu do szczęścia: „Pragnienie szczęścia jest więc tą nigdy nie przestającą działać sprężyną

${ }^{31}$ Por. J. Woroniecki, Katolicka etyka wychowawcza, t. I, Lublin 2002, s. 38-39, 101-102; tenże, Paedagogia perennis (Św. Tomasz a pedagogika nowożytna), „Przegląd Teologiczny” 5 (1924), s. 154, 156-157; tenże, Studium nad kardynalnq cnota roztropności, „Kwartalnik Teologiczny Wileński” 1-2 (1923-1924), s. 229; tenże, Katolickość tomizmu, Lublin 1999, s. 23-24; tenże, Metoda i program nauczania teologii moralnej, Lublin 1922, s. 15-22; tenże, Rozwój osobistości człowieka, w: tenże, Wychowanie człowieka. Pisma wybrane, Kraków 1961, s. 72-73. 
całej naszej działalności moralnej; zawiera ono w sobie pożądanie ukojenia wszystkich naszych potrzeb, pragnień, aspiracji we wszystkich dziedzinach, czy to niższych zmysłowych, czy też wyższych duchowych, tak iżby nam niczego nie brakowało, co by nam mogło ból, przykrość lub niezadowolenie i tęsknotę sprawić" 32 .

Moralne wybory człowieka są więc warunkowane nie tylko specyfiką poznania prawdy o rzeczywistości, ale także jakością woli konkretnego człowieka $^{33}$. Ta z kolei związana jest z dobrem, do którego lgnie wola, upatrując w nim możliwość zaspokojenia własnego pragnienia szczęścia ${ }^{34}$. Dobrami, do których zdobycia może zmierzać, mogą stać się: przyjemności zmysłowe, dobro bliskich osób, dobro wspólne w życiu społecznym, Bóg, własna doskonałość.

Związek między jakością dobra, będącego celem ludzkiego życia, a moralnością konkretnej jednostki jest, zdaniem Woronieckiego, szczególnie ważny w dziedzinie wychowania. Woroniecki zwraca uwagę, że rozwój moralny nie polega na urabianiu jednostki według wcześniej założonego ideału, ale na ukazaniu jej autentycznego dobra, którego dojrzewający człowiek może zapragnąc ${ }^{35}$. Jak mówi: „Kto żadnego celu sobie nie postawi, kto go nie zapragnie, nie umiłuje i nie postanowi osiągnąć, dla takiego drogowskazy nie mają znaczenia, nawet na nie nie spojrzy; takiemu prawić o ideałach, to tyle, co młócić pustą słomę" "36.

W tym kontekście należy zapytać o rolę wiary w podejmowaniu decyzji moralnych. Jeżeli założymy, że prawo moralne jest niezależne od światopoglądu, ponieważ wynika z prawa natury, a kodeks etyki chrześcijańskiej stanowi jedynie światopoglądową interpretację prawa natury, to znaczy, że wiara nie powinna zmieniać w żaden sposób norm moralnych. Jej wpływ na decyzje polega na motywowaniu do realizacji tych norm ${ }^{37}$.

Przenosząc powyższe stwierdzenia na płaszczyznę wychowania ekologicznego, można powiedzieć, że jego istotą nie jest przekaz doktryny mo-

${ }^{32}$ Tenże, Katolicka, t. I, s. 67-68.

${ }^{33}$ Por. tenże, Paedagogia perennis, s. 154-155; tenże, Dlugomyślność jako cnota właściwa wychowawcy, „Szkoła Chrystusowa” 4 (1930), s. 188-189.

34 Por. tenże, Katolicka, t. I, s. 31-32.

${ }^{35}$ Por. tamże, s. 64-65; tenże, Studium, s. 229; tenże, Metoda i program, s. 56.

${ }^{36}$ Tenże, Katolicka, t. I, s. 65.

${ }^{37}$ Por. tenże, Moralność a religia, w: tenże, U podstaw kultury katolickiej, Lublin 2002, s. 62-70; tenże, Chrześcijańskie wychowanie charakteru wysnute z dogmatu, „Szkoła Chrystusowa” 2 (1935), s. 54-59; tenże, Społeczeństwo a wychowanie, „Rok Polski” 8 (1916), s. 25-26; tenże, Miłość chrześcijańska jako przyjaźń z Bogiem wedle nauki św. Tomasza z Akwinu, w: Przyjaźń chrześcijańska. Zbiór studiów, Kielce 1948, s. 73-75; tenże, O ton Akcji Katolickiej, Warszawa 1923, s. 6-9. 
ralnej (choć stanowi on niezwykle ważny element tego wychowania), ale wpisanie postaw, uwzględniających ochronę przyrody, w realizację podstawowych celów, do których zmierza człowiek w swym życiu i których realizację uznaje za sens własnego życia. W przypadku chrześcijaństwa jest to wpisanie ochrony przyrody $\mathrm{w}$ drogę człowieka do osiągnięcia zjednoczenia z Bogiem. Słuszność tego sformułowania potwierdza Jan Paweł II w Orędziu na XXIII Światowy Dzień Turystyki, gdy mówi: „Wierzący czerpie $\mathrm{z}$ wiary skuteczną motywację kształtującą jego relację ze środowiskiem oraz pobudzającą go, by starał się zachować jego integralność" ${ }^{38}$. Chrześcijańska edukacja ekologiczna powinna więc podejmować próby wpisania działań na rzecz ochrony przyrody w transcendentną perspektywę ludzkiego życia. Biorąc pod uwagę współczesny kontekst kulturowy, oznacza to jednak przede wszystkim budowanie owej transcendentnej perspektywy, która mogłaby motywować do działań na rzecz środowiska przyrodniczego. Innymi słowy, oznacza to konieczność podejmowania działań, umożliwiających człowiekowi spojrzenie na siebie jako na istotę pozostającą w ontycznej relacji z Bogiem. Jaki potencjał posiada w tym zakresie turystyka?

\section{Edukacyjny potencjal turystyki w dziedzinie ukazywania ontycznej relacji między człowiekiem i Bogiem}

Turystyka może przenosić człowieka albo w rzeczywistość stworzoną przez człowieka, albo w świat przyrody, która wcale lub w niewielkim stopniu została przekształcona przez ludzkość. To, gdzie znajdzie się turysta, jaki cel podróży wybierze, nie pozostaje bez znaczenia dla prawd, które mogą zostać przez niego odkryte. Rzecz, z którą styka się, dostarcza mu bowiem wielu informacji. Udając się do miejsca pełnego dzieł sztuki, które powstawały na przestrzeni wieków, odkrywa nie tylko piękno samych tych dzieł, ale również specyfikę kultury, w której powstało zapotrzebowanie na te dzieła i w której znaleźli się twórcy, gotowi podjąć wyzwanie zmierzenia się z owymi potrzebami. Nie inaczej jest z przyrodą, która - mimo całej naszej wiedzy o prawach, jakim podlegał świat na drodze ewolucji - ciągle skłania do postawienia pytania o ostateczną przyczynę piękna, którego człowiek doświadcza w trakcie wędrówki.

Taki sposób spojrzenia na świat podpowiada Biblia. Mimo że jej przesłanie zogniskowane jest na Jezusie Chrystusie, to pozostaje ona również księgą, w której zapisane zostały koleje odkrywania Boga przez człowieka

38 Jan Paweł II, Ekoturystyka kluczem do właściwego rozwoju. Orędzie na XXIII Światowy Dzień Turystyki 2002, „L'Osservatore Romano” 9 (2002), s. 56-57. 
na drodze kontemplacji stworzonego świata. Dla autorów biblijnych świat jest przede wszystkim teofanią ${ }^{39}$. Prawdę tę wyraża autor Księgi Mądrości: „Bo z wielkości i piękna stworzeń poznaje się przez podobieństwo ich Stwórcę" $(13,5)$. Odkrycie świata jako symbolu wskazującego na Boga-Stwórcę obecne jest nie tylko w Księdze Mądrości. Już zamieszczona w Księdze Rodzaju narracja o Stworzycielu i stworzeniach nie ma charakteru naukowego wykładu o stworzeniu świata, ale stanowi zachętę do medytacji nad czynami Boga, który z bezładu wyprowadził porządek, harmonię i piękno ${ }^{40}$. Obszerne wywody na temat Boga, Stwórcy świata, znajdujemy w Księdze Hioba (38-41), Księdze Izajasza $(6,3 ; 40,12-26 ; 66,1-2)$ oraz wielu psalmach (Ps 19, 1-7; 89, 6-15; 93; 96; 98; 104; 136; 148) ${ }^{41}$. Szczególnie psalmy łączą kontemplację świata z odkryciem Boga jako jego Stwórcy. Za przykład może służyć fragment psalmu, zatytułowanego Chwała Boża w przyrodzie i Prawie: „Niebiosa głoszą chwałę Boga, działo rąk Jego nieboskłon obwieszcza" $(19,2)$. Bardzo wymowne są również słowa św. Pawła na temat Boga, zawarte w Liście do Rzymian: „Albowiem od stworzenia świata niewidzialne Jego przymioty - wiekuista Jego potęga oraz bóstwo - stają się widzialne dla umysłu przez Jego dzieła" $(1,20)$. Nowotestamentalne przepowiadanie w wielu innych miejscach odwołuje się do tego, co człowiek może odkryć na drodze rozumnych poszukiwań (np. Dz 14, 15; 17, 16-31; 2 Kor 4, 6; Ap 10, 6). Biblia nieustannie podkreśla więc prawdę, że nie tylko księga Objawienia odkrywa prawdę o Bogu, ale również księga natury. Jan Paweł II w orędziu na XXIII Światowy Dzień Turystyki stwierdził, że w całej Biblii ,,piękno świata stworzonego jest znakiem objawiającym wielkość i dobroć Boga" ${ }^{42}$. Oczywiście, nie tylko Biblia traktuje poznanie świata jako drogę do stwierdzenia istnienia Absolutu. Podobne tezy znajdujemy na terenie filozofii ${ }^{43}$, czy w literaturze pięknej, będącej odzwierciedleniem przeżyć i doświadczeń człowieka obcującego z przyrodą.

39 Por. H. Witczyk, Teofanijny wymiar świata (Rdz 1,1-2,3), w: M. U. Mazurczak, J. Patyra, M. Żak (red.), Obraz i przyroda, Lublin 2005, s. 29; tenże, Stworzenie a ekologia w świetle $R d z$ 1, 1-2, 3, „Człowiek i Przyroda” 10 (1999), s. 42-48; W. Bołoz, dz. cyt., s. 345; J. Salij, dz. cyt., s. 157; C. Lesquivit, P. Grelot, Świat, w: X. Léon-Dufour (red.), Stownik Teologii Biblijnej, Poznań 1990, s. 954; W. Knoch, dz. cyt., s. 15; S. Zięba, dz. cyt., s. 15; J. Moltmann, dz. cyt., s. 120-126.

${ }_{40}$ Por. J. R. Porter, Stworzenie, w: B. M. Metzger, M. D. Coogan (red.), Stownik wiedzy biblijnej, Warszawa 1997, s. 721; H. Witczyk, Teofanijny, s. 34-35, 40-42; P. Auvray, Stworzenie, w: X. Léon-Dufour (red.), dz. cyt., s. 908-909, 911.

${ }^{41}$ Por. P. Auvray, dz. cyt., s. 911; J. Salij, dz. cyt., s. 164; S. Zięba, dz. cyt., s. 16.

42 Jan Paweł II, Ekoturystyka, s. 56.

${ }^{43}$ Zob. np. Z. Zdybicka, Drogi afirmacji Boga, w: M. A. Krąpiec, S. Kamiński, Z. Zdybicka, A. Maryniarczyk, P. Jaroszyński, Wprowadzenie do filozofii, Lublin 1996, s. 437-449; S. Kowalczyk, Drogi ku Bogu, Wrocław 1983. 
Wędrówka wśród przyrody, doświadczenie jej piękna, jest zatem dla człowieka okazją do postawienia pytania o Absolut, który jest przyczyną świata. Szczególnie góry zdają się skłaniać do refleksji na temat Stwórcy. Już w starożytności postrzegano je jako miejsca zetknięcia z niebem, a nawet przebywania bogów, co prowadziło do czynienia niższych pagórków naturalnymi sanktuariami. Stały się zatem symbolem bliskości Boga ${ }^{44}$. Wędrówka w góry pozwala oderwać się od «dolinnej» atmosfery i sięgnąć wyżej nie tylko wzrokiem, ale przede wszystkim «duchem»; to czas doświadczenia żywiołu gór i odkrywania sacrum w otaczającej górskiej przyrodzie $^{45}$. Jak mówi Maciej Ostrowski, w górach podziw widzialnego świata stworzeń otwiera drogę ku fascynacji światem niewidzialnym - samym Bogiem, gdyż majestat gór przypomina wielkość i bezgraniczne piękno Boga. Góry są śladem wszechmocy Boga, pozostawionym dla duchowego podniesienia człowieka ${ }^{46}$. Zresztą, nie tylko góry, ale cały świat, który jest kontekstem ludzkiej egzystencji, stanowi dla człowieka znak. Ów «kon-tekst» próbuje on odczytać, szukając powiązań między światem a sobą, między kosmosem a Bogiem ${ }^{47}$. Jest to przyrodzona teologia rozumu ${ }^{48}$. Turystyka będąc spotkaniem z przyrodą - może zatem stać się przestrzenią spotkania z Bogiem ${ }^{49}$.

Owo spotkanie ma swoje uwarunkowania także po stronie człowieka. Mówiąc o tym, jak turystyka może przyczynić się do odkrycia przez człowieka ontycznej relacji między nim a Bogiem, zadać należy więc również pytanie o to, jak wędrówka zmienia spojrzenie człowieka na samego siebie. Wprowadzić może ona nowe okoliczności do oceny własnej pozycji w stworzonym świecie. Stawia bowiem człowieka w niecodziennych sytuacjach, sytuacjach nieprzewidzianych, na które człowiek nie był przygotowany, co prowadzi do utraty poczucia bezpieczeństwa. Takie poczucie bezpieczeństwa stwarza człowiekowi zazwyczaj miejsce, w jakim on zamieszkuje. Tam

${ }^{44}$ Por. T. Jelonek, Góry w Biblii, w: XIII Seminarium, s. 29.

${ }^{45}$ Por. Z. Pytel, ,, Orla Perć” na fotografii, w: XIII Seminarium, s. 89; A. Szebesta, Bóg w poezji tatrzańskiej, w: XIII Seminarium, s. 45.

${ }^{46}$ Por. M. Ostrowski, Jana Pawła II szlaki, s. 20; zob. także: tenże, Wychowawcza rola sakralnego krajobrazu, w: M. Ostrowski, J. Partyka (red.) dz. cyt., s. 52-53; tenże, Turystyka i przyroda w teologicznej refleksji Jana Pawła II, w: M. Ostrowski, I. Sołjan (red.), dz. cyt., s. 29-31.

47 Por. L. Turos, Turystyka, s. 104-105; T. Paszkowska, „Pochwała stworzeń” jako forma uwielbienia Stwórcy, w: M. U. Mazurczak, J. Patyra, M. Żak (red.), dz. cyt., s. 389; B. Johnson, On the Spiritual Benefits of Wilderness, „International Journal of Wilderness” 8 (2002), n. 3, s. 29.

48 Por. J. Woroniecki, Katolicka, t. I, s. 75-76.

${ }^{49}$ Por. K. Przecławski, Życie - to podróż, Warszawa 2005, s. 128. 
zna odległości, które musi przemierzyć, zna swoje możliwości, wie, w jaki sposób poradzić sobie w trudnościach, do kogo zwrócić się o pomoc i w jaki sposób się zachować. Turystyka zmienia tę sytuację. Góry na przykład każą człowiekowi spojrzeć na siebie z wielką pokorą, ujrzeć właściwą skalę rzeczywistości bytu, pozwalają odczuć prawdę, że jest się tylko stworzeniem ${ }^{50}$. Jeżeli z wędrówką wiążą się ponadto niesprzyjające okoliczności pogodowe, na przykład burza, człowiek zaczyna wówczas zdawać sobie sprawę z własnej przygodności, z własnej śmiertelności ${ }^{51}$. Żyjąc w świecie rozpoznanym, w którym człowiek czuje się bezpiecznie, wie on o własnej śmiertelności, a równocześnie prawda ta pozostaje na co dzień poza jego świadomością. Odkrycie w trakcie wędrówki własnej sytuacji bytu stworzonego, przygodnego, może być więc impulsem do odkrycia ontycznej relacji między sobą a Bogiem.

W turystyce istotne jest również to, że odrywa ona człowieka od jego codziennych obowiązków, zadań i stwarza przestrzeń do milczenia i refleksji nad sobą, do zagłębienia się we własne wnętrze. W dzisiejszym świecie dominuje pośpiech, hałas, brak czasu na głębszą refleksję. Doświadczają tego szczególnie mieszkańcy miast ${ }^{52}$. Ciągły pośpiech i związane z nim rozproszenie, słuchanie przekazu mediów podczas wykonywania szeregu różnych czynności - powierzchowne i pozbawione głębszej refleksji - sprawiają, że zanika zdolność milczenia połączonego z refleksją ${ }^{53}$. Nawet jeżeli współczesny człowiek milczy zewnętrznie, to wewnętrznie nie funkcjonuje on w przestrzeni ciszy. W milczeniu wewnętrznym chodzi bowiem o to, aby wyciszyć wewnętrzny hałas, przeżyć radości, smutki, sukcesy, klęski i uporządkować siebie ${ }^{54}$; aby milczenie było przestrzenią spotkania samego siebie; aby człowiek w końcu trafił «do siebie» ${ }^{55}$. Kontakt z dziką naturą to sposobność do samotności i wyciszenia, które nie tylko będą przyczyniać się do regeneracji sił psychicznych i fizycznych ${ }^{56}$, ale mogą stać się katalizatorem wielu

${ }^{50}$ Por. M. Ostrowski, Jana Pawła II szlaki, s. 20; K. Przecławski, Życie, s. 128.

${ }^{51}$ Por. A. Bańka, Psychologiczne korzyści kontaktu z przyroda i doświadczeń dzikości, w: B. Przyborowska (red.), dz. cyt., s. 190; R. Winiarski, J. Zdebski, dz. cyt., s. 62-63.

${ }_{52}$ Por. P. A. Bell, Th. C. Greene, J. D. Fisher, A. Baum, Psychologia środowiskowa, Gdańsk 2004, s. 418-433; A. Bańka, Społeczna psychologia środowiskowa, Warszawa 2002, s. 222-224.

${ }_{53}$ Por. K. T. Wencel, Pedagogia milczenia, „Paedagogia Christiana” 1 (2004), s. 54.

${ }^{54}$ Por. W. Zatorski, Milczeć, aby ustyszeć, Kraków 2007, s. 32; L. Knabit, Znajdźmy czas na ciszę. O ciszy, gadulstwie oraz o zlym i dobrym milczeniu z o. Leonem Knabitem, benedyktynem z Tyńca, rozmawia Błażej Tobolski, „Przewodnik Katolicki” 5 (2008), s. 24-25.

55 Por. A. Grün, Potrzeba milczenia, Kraków 2001, s. 19-20, 25; M. Zawada, Zaślubiny z samotnościa, Kraków 1999, s. 27-28; K. T. Wencel, Milczenie, Kraków 2001, s. 44-47.

${ }^{56}$ Por. R. Winiarski, J. Zdebski, dz. cyt., s. 61. 
korzyści psychicznych i duchowych ${ }^{57}$. Stwarza on więc okazję, aby odkryć najgłębsze fundamenty własnej egzystencji i w pełniejszy sposób poznać samego siebie. Będąc bardziej skupionym wewnętrznie, w warunkach sprzyjających kontemplacji, człowiek może rozważać wydarzenia swego życia, szukając ich najgłębszego sensu ${ }^{58}$.

Turystyka jawi się więc jako przestrzeń, w której człowiek nie tylko poznaje świat i prawa nim rządzące, istotne między innymi w dziedzinie ekologii, ale ma także okazję do spojrzenia na siebie w perspektywie własnej relacji z Bogiem ${ }^{59}$. Takie spojrzenie jest $\mathrm{z}$ kolei istotne - jak stwierdziliśmy - w samym wychowaniu moralnym. Moralność konkretnego człowieka uwarunkowana jest bowiem celem, do którego zmierza on w swoim życiu. Jeżeli więc turysta odkrywa swoje życie jako historię dialogu z Bogiem, to można mieć nadzieję, że w dialog ten włączona zostanie również przyroda, o którą troska jest zadaniem powierzonym człowiekowi. Turystyka jawi się zatem jako odpowiednie narzędzie do prowadzenia edukacji chrześcijańskiej w dziedzinie ekologii. Wykorzystując ją, należy mieć jednak świadomość zagrożeń związanych z aktywnością turystyczną we współczesnym świecie. Kończąc niniejsze rozważania naświetlmy zatem pokrótce to zagadnienie.

\section{Zagrożenia związane z turystyką}

Mówiąc o możliwościach wykorzystania turystyki w edukacji ekologicznej, także tej, prowadzonej $\mathrm{w}$ ramach chrześcijaństwa, należy zdawać sobie sprawę, że nie można bezkrytyczne podchodzić do turystyki, ale należy wykazać wiele roztropności w jej organizacji. Turystyka staje się obecnie zjawiskiem powszechnym ${ }^{60}$, ale jej coraz szersze wykorzystanie wyznaczane jest tylko $\mathrm{z}$ jednaj strony możliwościami w zakresie wspierania rozwoju człowieka $^{61}$. Z drugiej strony, wpisuje się ona w kształt kultury konsumpcyjnej, stając się źródłem jedynie wypełnionej przyjemnościami rozrywki,

${ }^{57}$ Por. A. Bańka, Psychologiczne korzyści, s. 188.

58 Por. M. Ostrowski, Jana Pawła II szlaki, s. 17-19; tenże, Turystyka i przyroda, s. 26-27.

${ }^{59}$ Dostrzeżenie owej perspektywy może zaowocować chociażby modlitwą. Por. A. Szebesta, dz. cyt., s. 47.

${ }^{60}$ Por. L. Turos, Wprowadzenie do wiedzy o turystyce edukacyjnej, Warszawa 1997, s. 95-97; R. Winiarski, J. Zdebski, dz. cyt., s. 19.

${ }^{61} \mathrm{O}$ wartościach turystyki w dziedzinie kształcenia i edukacji, wychowania moralnego i rozwoju emocjonalnego, profilaktyki i resocjalizacji zob. K. Przecławski, Turystyka, s. 71-78; K. Denek, $W$ kręgu, s. 133-141. 
której nie towarzyszy żaden wysiłek i zmęczenie ${ }^{62}$. Organizując turystykę można ją więc wpisać albo w proces rozwoju człowieka, albo przyczynić się do jeszcze głębszego osadzenia człowieka w kulturze masowej, w kulturze konsumpcji. Jak mówią Ryszard Winiarski i Janusz Zdebski:

przeciętny «turysta masowy» podróżuje tak, jak żyje na co dzień: w tłumie, coraz sprawniej, taniej i szybciej, zwiedzając najczęściej bezrefleksyjnie, coraz więcej i pobieżniej. [...] w miejscach, do których trafia, napotyka kicz, inscenizację i specjalnie spreparowane dla niego środowisko: sztuczny śnieg na stokach narciarskich, sztucznie usypane plaże i wydmy na tropikalnych wyspach oraz przebranych na czas jego pobytu tubylców, gotowych pozować do pamiątkowych fotografii. Kreowanie sztucznych atrakcji turystycznych, kulturowo wyjałowionych, nieprzypisanych do miejsca i pozbawionych historii sprawia, że «rodzi się» nowa generacja turystów - postturyści, którym wystarczają doskonałe repliki zabytków i sztuczne atrakcje, dostarczające wyrafinowanych i precyzyjnie skalkulowanych przeżyć i doświadczeń. Wizyta w parku rozrywki, w którym można znaleźć wszystko, co tylko ludzka wyobraźnia i technika są w stanie stworzyć, zastępuje im kontakt z realnym światem kultury ${ }^{63}$.

Trudno przypuszczać, aby tak zorganizowana turystyka przyczyniała się w jakikolwiek sposób do odkrywania Absolutu oraz konieczności uwzględnienia dobra przyrody na drodze zmierzania do Niego. Będąc uczestnikiem wycieczki, człowiek styka się bowiem z dziełami, wskazującymi na możliwości człowieka. Z jednej strony, wielkość człowieka odsyła również do pytania o Stwórcę, ale z drugiej strony, dzieło Boga zostaje w jakiś sposób przesłonięte twórczością człowieka i w wielu przypadkach pozostaje niezauważone ${ }^{64}$.

Turystyka, która wynika z kultury konsumpcji, może ponadto prowadzić do niepożądanych konsekwencji w wielu płaszczyznach. Po pierwsze, może być okazją do negatywnych zachowań samego turysty. Uwolnienie się od nacisku norm społecznych może sprzyjać łatwej zabawie, połączonej z brakiem odpowiedzialności, niebezpiecznej dla zdrowia, może sprzyjać

${ }^{62}$ Por. P. Rymarczyk, Turystyka jako zwierciadło współczesnej kultury konsumpcyjnej, w: J. Kosiewicz, K. Obodyński (red.), Turystyka i rekreacja. Wymiary teoretyczne i praktyczne, Rzeszów 2006, s. 28. K. Przecławski, Turystyka, s. 80-81; R. Winiarski, J. Zdebski, dz. cyt., s. 23-24; Z. Gosz, Edukacja ekologiczna jako inspirujacy czynnik w procesie ksztattowania świadomości ekologicznej społeczeństwa XXI wieku, w: J. M. Dołęga, J. W. Czartoszewski, A. Skowroński (red.), dz. cyt., s. 182-185.

${ }^{63}$ R. Winiarski, J. Zdebski, dz. cyt., s. 20-21.

${ }^{64}$ Por. W. Knoch, dz. cyt., s. 9. 
sięganiu po alkohol, narkotyki, przygodne kontakty seksualne ${ }^{65}$. Po drugie, turystyka taka może prowadzić do zniszczenia odwiedzanych terenów ${ }^{66}$. Jan Paweł II w Orędziu na XXIII Światowy Dzień Turystyki zauważył: „Czyż można [...] zaprzeczyć, że ludzkość przeżywa dziś, niestety, kryzys ekologiczny? Do zniszczenia natury przyczynił się i nadal przyczynia barbarzyński model turystyki, obejmujący między innymi budowanie infrastruktury turystycznej bez planowania uwzględniającego jej wpływ na środowisko"67. Po trzecie, turystyka może wprowadzać niepokój i destabilizować lokalne społeczności, traktując instrumentalnie zarówno pozostałości «pierwotnych cywilizacji» i «nadal żywe obrzędy inicjacyjne», jak i przedstawicieli lokalnych społeczności, a szczególnie kobiety i dzieci68.

Jeżeli turystyka ma stać się metodą chrześcijańskiej edukacji w dziedzinie ekologii, to jej organizatorzy muszą zdawać sobie sprawę z jej ograniczeń i niebezpieczeństw z nią związanych, tak aby planując aktywność turystyczną, przyczyniali się do dobra zarówno samego turysty, jak i tych ludzi i terenów, które są przez niego odwiedzane. Wymaga to dowartościowania takich form turystyki, które odznaczają się ,większym szacunkiem dla środowiska, większym umiarkowaniem pod względem korzystania z bogactw naturalnych i większą odpowiedzialnością za kultury lokalne"69.

\section{Podsumowanie}

W Orędziu na Światowy Dzień Turystyki w roku Jubileuszu 2000 lat chrześcijaństwa Jan Paweł II powiedział: „Pragnę z całego serca, aby turystyka była zawsze sposobnością do owocnych spotkań: do spotkania z Bogiem, który w stworzeniu i w dziełach ludzkich ukazuje nam swoją miłość i opatrzność; do spotkania z soba samym, w postawie milczącej refleksji i wsłuchiwania się w głos własnego wnętrza; do spotkania z innymi, które pozwoli budować zgodne współistnienie między ludźmi i narodami’”70.

${ }^{65}$ Por. R. Winiarski, J. Zdebski, dz. cyt., s. 16, 21-22; K. Przecławski, Turystyka, s. 81-82; P. Rymarczyk, dz. cyt., s. 28.

${ }^{66}$ Por. K. Przecławski, Życie, s. 122; L. Turos, Wprowadzenie, s. 119-123.

${ }^{67}$ Jan Paweł II, Ekoturystyka, s. 56-57.

${ }^{68}$ Por. tenże, Turystyka $w$ stużbie pokoju $i$ dialogu między cywilizacjami. Orędzie na XXII Światowy Dzień Turystyki 2001, „L'Osservatore Romano” 9 (2001), s. 4-6; R. Winiarski, J. Zdebski, dz. cyt., s. 58, 71.

${ }^{69}$ Jan Paweł II, Ekoturystyka, s. 56-57.

${ }^{70}$ Tenże, Technika i przyroda: dwa wyzwania dla turystyki na progu XXI stulecia. Orędzie na XXI Światowy Dzień Turystyki 2000, nr 4, w: M. Ostrowski (red.), Duszpasterstwo, s. 41. 
W turystyce tkwi niewątpliwie olbrzymi potencjał w zakresie rozwoju samego turysty, budowania wspólnoty i pokoju między ludźmi, likwidacji różnic ekonomicznych. Stąd jest ona wykorzystywana coraz szerzej w różnych dziedzinach życia ludzkiego, zarówno indywidualnego, jak i społecznego. Jak wynika z prowadzonych $\mathrm{w}$ artykule poszukiwań, jest ona również szansą dla edukacji chrześcijańskiej, a szczególnie edukacji moralnej dotyczącej kwestii ochrony przyrody. W jej przestrzeni dokonuje się bowiem nie tylko poznanie świata, $\mathrm{z}$ jego prawidłowościami oraz celami wpisanymi $\mathrm{w}$ jego naturę, ale jest ona również szansą na inne spojrzenie na siebie i odkrycie własnego istnienia w kontekście relacji z Bogiem. Owa relacja stanowi z kolei dodatkową motywację do ochrony przyrody, która - zgodnie ze słowami biblijnego Objawienia - powierzona została trosce człowieka. Organizując jednak turystykę, pamiętać należy, że tak samo może ona przyczyniać się do rozwoju człowieka i świata, jak i stać się przestrzenią jego degradacji. W ostateczności to człowiek - organizator i uczestnik wypraw turystycznych - musi podjąć odpowiedzialność moralną za skutki własnej aktywności.

\section{Turism in the Christian Ecological Education (Summary)}

Talking about ecological education in the religious education undertaken in Christian communities we should not ask 'if' but 'how' it should appear what the rules governing it are and what the methods and means should be used. The paper aims at researching a fragment of reality in terms of Christian religious education in terms of ecology, and more specifically it discusses the issue of using tourism as a method in the area of education mentioned above. Researching the problem the author considered the specifics of Christian ethics which relates to both the natural cognition as well as to the Revelation. It also displays a difference between ethics and morality, because in the latter one the motivation of will to undertake certain actions and discard some is crucial. The research in the article attempts at displaying that tourism is a chance for Christian moral education concerning nature. In its space not only a recognition of the world with its rules and aims ascribed to its nature takes place but also it can be a chance to look at oneself from a different perspective and discovering oneself in the context of relation with God - nature makes man question the idea of Absolute being the cause of the world as well as it also helps to look at oneself as a weak creature, not capable of coping with many situations and finally, it creates the space of silence in which a tourist can reflect on himself and his own life. The recognition of the onthological relation between man and God is another motivation to protect the environment, which according to the words of biblical Revelation was given to man to take care of. 